\title{
Les sites fortifiés et les occupations de hauteur en Auvergne de l'âge du Bronze final à la fin de l'âge du Fer
}

\section{Patrick Pion}

\section{Q OpenEdition}

\section{Journals}

Édition électronique

URL : http://journals.openedition.org/adlfi/4745

ISSN : 2114-0502

Éditeur

Ministère de la culture

Référence électronique

Patrick Pion, « Les sites fortifiés et les occupations de hauteur en Auvergne de l'âge du Bronze final à la fin de l'âge du Fer », ADLFI. Archéologie de la France - Informations [En ligne], Auvergne, mis en ligne le 01 mars 2006, consulté le 03 mai 2019. URL : http://journals.openedition.org/adlfi/4745

Ce document a été généré automatiquement le 3 mai 2019.

(c) Ministère de la Culture et de la Communication, CNRS 


\title{
Les sites fortifiés et les occupations de hauteur en Auvergne de l'âge du Bronze final à la fin de l'âge du Fer
}

\author{
Patrick Pion
}

Identifiant de l'opération archéologique : 111

Date de l'opération : 2006 (PC)

1 L'année 2006 a été consacrée à l'actualisation des inventaires par départements. Le dépouillement conduit à un bilan très contrasté pour les trois dont l'inventaire est terminé : Allier, Haute-Loire et Cantal (voir tableau). Le nombre de sites potentiels varie du simple au double d'un département à l'autre, mais le nombre de sites avec occupation (s) attestée(s) pendant la protohistoire est, en revanche, pratiquement équivalent. Les situations sont cependant fortement contrastées, avec une opposition flagrante de l'Allier aux deux départements de montagne :

2 - très forte majorité de sites fortifiés aménagés dans l'Allier, alors que la situation est exactement inverse avec de nombreux sites de hauteur naturellement fortifiés et sans aménagements attestés dans le Cantal et la Haute-Loire ;

3 - dispersion homogène des sites fortifiés à l'échelle du département avec une distribution assez équitable entre les différents bassins fluviaux dans l'Allier, s'opposant à des concentrations marquées sur les vallées de l'Allagnon et de la Loire qui laissent par ailleurs de vastes déserts pour la Haute-Loire et le Cantal.

4 (Fig. $\mathrm{n}^{\circ} 1$ : Répartition des sites par département prospecté)

5 Ces disparités s'expliquent seulement pour partie par l'histoire de la recherche, ou par les différences de relief et de topographie. Cependant, avant d'interpréter ces variations dans les modes d'occupation de l'espace en termes de formes d'organisations territoriales différentes sur les marges nord et sud de ce qui deviendra le territoire arverne, il conviendra de s'assurer de la réalité de ces concentrations en prospectant intensivement 
des fenêtres vierges. Il conviendra également d'explorer un possible rapport des secteurs à forte densité avec la localisation de gîtes de matières premières particulières et recherchées (métaux, sel, etc.). Les prospections ont par ailleurs conduit à dater de La Tène plusieurs enceintes réputées anhistoriques et à découvrir plusieurs sites totalement inédits. Les sondages opérés dans les collections anciennes montrent par ailleurs leur riche potentiel et la nécessité d'en reprendre l'étude à la lumière des bases typochronologiques actuelles.

\section{ANNEXES}

Fig. $\mathrm{n}^{\circ} 1$ : Répartition des sites par département prospecté

\begin{tabular}{|c|c|c|c|c|c|}
\hline & $\begin{array}{c}\text { Sites } \\
\text { potentiels }\end{array}$ & $\begin{array}{c}\text { Signalements } \\
\text { avant } 1940\end{array}$ & Sites fortifiés & $\begin{array}{c}\text { Sites proto «non } \\
\text { fortifiés» }\end{array}$ & Total sites proto \\
\hline ALLIER & 91 & 60 & 20 & 3 & $\mathbf{2 3}$ \\
\hline CANTAL & 54 & 30 & 8 & 17 & $\mathbf{2 5}$ \\
\hline HAUTE-LOIRE & 32 & 3 & 10 & 16 & $\mathbf{2 6}$ \\
\hline
\end{tabular}

Auteur(s) : Pion, Patrick (SUP). Crédits : Pion Patrick SUP (2006)

INDEX

Index géographique : Auvergne

operation Projet collectif de recherche (PCR)

Index chronologique : âge du Fer, Bronze final, Empire romain

peuple Arverne

Thèmes : forteresse, fortification, inventaire, site de hauteur, site de plaine

\section{AUTEURS}

\section{PATRICK PION}

SUP 